\title{
First discovers \\ of Pleistocene authigenic carbonate crusts (ACC) at the Mendeleev Rise, Arctic Ocean
}

\author{
Aleksey Pakhalko ${ }^{1}$, Aleksey Krylov², Elena Mirolyubova ${ }^{2}$, Ekaterina Taldenkova ${ }^{2}$, \\ Pavel Rekant ${ }^{1}$
}

${ }^{1}$ A.P. Karpinsky Russian Geological Research Institute (VSEGEI); Saint-Petersburg; e-mail: Aleksey_Pahalko@vsegei.ru

${ }^{2}$ VNIIOkeangeologia, Saint-Petersburg

(C) 2016 Authors. This is an open access publication, which can be used, distributed and reproduced in any medium according to the Creative Commons CC-BY 4.0 License requiring that the original work has been properly cited.

The Mendeleev Rise (or Mendeleev Ridge) is a part of Central Arctic Uplifts domain that extends from the Eastern Siberian Shelf to the central areas of the ocean, where it is adjacent to the Alpha Ridge bisecting the Amerasian Basin. The crust of Mendeleev Rise belongs to the continental type (Poselov et al. 2007).

New geological, geophysical and tectonic data were obtained within Alpha-Mendeleev Rise after few expeditions to Arctic Ocean in year 2000, 2005 and 2012. Thousands of rock fragments were dredged: $50-65 \%$ - carbonate rocks (mainly dolomite and limestone); $20-25 \%$ - sandstones, siltstones, mudstones; 5-20\% - igneous rocks (mainly granites, gabbro-dolerite and few types of basalt); $\sim 10 \%$ - metamorphic rocks (mainly greenschist facies). Light dolomites with little flora and fauna represent about two-thirds of the total amount of carbonate rocks, the rest are limestones, often containing well-preserved faunal remains. Paleontological study of limestones show abundance of D-P fauna remnants that give us an evidence of structural connection of Mendeleev Rise and Wrangel Island (Morozov et al. 2013).

Carbonate crusts were dredged from steep slopes $\left(25-29^{\circ}\right)$ with neotectonic faults on two sites at water depth more than $2 \mathrm{~km}$ during expedition "Arktika-2012". Primary study showed that crusts compose of strong matrix with rounded and angular debris of local (edaphogenic) material: dolomites, dolerites, granites, metasomatic and terrigenous rocks of different size $(0.5 \mathrm{~mm}$ to $5 \mathrm{~cm})$ (Morozov et al. 2013, Kremenetskii et al. 2015).

Three samples of matrix and two of soft clay-carbonate crust's cover were selected for detailed analysis. Petrographic features were studied using optical microscope, microprobe and X-ray analysis. Chemical elements analysis was performed with XRF and ICP-MS. All analyses were carried out in A.P. Karpinsky Russian Geological Research Institute (VSEGEI) in Saint-Petersburg.

AAC's Matrix studied with microprobe in details and consists of fine-grained calcite with angular quartz grains from $1 \mu \mathrm{m}$ to $300 \mu \mathrm{m}$. X-ray analysis shows calcite predominance in the matrix $(>70 \%)$, rest content is presented with clasts of quartz, illite and albite - about $10 \%$, dolomite, chlorite, montmorillonite, chamosite $-1-2 \%$.

Clasts of local debris are presented by two association:

1) large, mainly angular clasts with size from $0.5 \mathrm{~mm}$ to $5 \mathrm{~cm}$;

2) small, mainly rounded clasts with size from $200 \mu \mathrm{m}$ to $0.5 \mathrm{~mm}$.

Surface of matrix and debris is covered with soft rose clay-carbonate mass. Mineral content of clay-carbonate mass is: quartz and illite $-25-30 \%$, calcite and albite $15-20 \%$, chlorite, orthoclase, halite, dolomite, montmorillonite $-1-5 \%$.

Chemical composition (in percents) of matrix is close to clay-carbonate terrigenous rocks: $\mathrm{SiO}_{2}-18$, $\mathrm{Al}_{2} \mathrm{O}_{3}-3.62, \mathrm{TiO}_{2}-0.2, \mathrm{Fe}_{2} \mathrm{O}_{3} \mathrm{t}-1.4, \mathrm{MnO}-0.05$, 
$\mathrm{MgO}-2.35, \mathrm{CaO}-39.2, \mathrm{Na}_{2} \mathrm{O}-0.18, \mathrm{~K}_{2} \mathrm{O}-0.47$, $\mathrm{P}_{2} \mathrm{O}_{5}-0.12$, L.O.I. - 34.3. Rose mass differs from matrix with silica $-46, \mathrm{CaO}-19$, higher alkalis $(\mathrm{Na}$ and $\mathrm{K})-1.15$ and 1.3. Difference in content of silica (18\% vs $46 \%)$, $\mathrm{CaO}(39.2 \%$ vs $19 \%)$ says that $\mathrm{AAC}$ matrix and rose mass have various sources.

In contrast to Paleozoic remnants in carbonates, the AAC contain planktonic and benthic foraminifera of Pleistocene age. In Arctic seas, these species are distributed in modern conditions mainly in places where the Gulf Stream arrives (Herman 1974).

These data indicates local origin of ACC, main evidences includes distribution, good preservation of samples, local debris in matrix, paleontological age. However, carbonates are very limited in the Arctic Ocean (Emelyanov 2005, Chierici \& Fransson 2009). In view of these parameters, AAC can't form by itself so it may be due only to external factors. Bottom water doesn't provide such factors. Neither necessary conditions nor material occur in these waters. So in our opinion AAC were formed with help of neotectonic fault which are supposed to be a possible path for hot fluids, which created the conditions for crusts forming and Paleozoic carbonate rocks was a source of $\mathrm{CaCO}_{3}$.

\section{REFERENCES}

Chierici M. \& Fransson A., 2009. Calcium carbonate saturation in the surface water of the Arctic Ocean: undersaturation in freshwater influenced shelves. Biogeosciences, 6, 2421-2432.

Emelyanov E.M., 2005. Barrier Zones in the Ocean. Springer-Verlag, Berlin - Heidelberg.

Herman Y., 1974. Arctic Ocean Sediments, Microfauna, and the Climatic Record in Late Cenozoic Time. [in:] Herman Y. (ed.), Marine Geology and Oceanography of the Arctic Seas, Springer-Verlag, New York, 283-348.

Kremenetskii A.A., Kostitsyn Yu.A., Morozov A.F. \& Rekant P.V., 2015. Sources of the magmatic rocks of the Mendeleev Rise, Arctic Ocean: Evidence from isotope-geochemical data. Geochemistry International, 53, 6, 487-500.

Morozov A.F., Petrov O.V., Shokal'skiy S.P., Kashubin S.N., Kremenetskiy A.A., Shkatov M.Yu., Kaminskiy V.D., Gusev Ye.A., Grikurov G.E., Rekant P.V., Shevchenko S.S., Sergeyev S.A., Shatov V.V., 2013. Novyye geologicheskiye dannyye, obosnovyvayushchiye kontinental'nuyu prirodu oblasti Tsentral'no-Arkticheskikh podnyatiy. Regional'naya Geologiya i Metallogeniya, 53, 34-55.

Poselov V.A., Verba V.V. \& Zholondz S.M., 2007. Typification of the Earth's crust of Central Arctic Uplifts in the Arctic Ocean. Geotectonics, 41, 4, 296-305. 